\title{
PERSPEKTIF ISLAM TENTANG PENDIDIKAN MULTIKULTURAL
}

\author{
Muzakkir \\ Fakultas Tarbiyah dan Keguruan UIN Alauddin Makassar
}

\begin{abstract}
Allah swt. creates human beings of male and female, nation and tribe to know each other. Humans can interact well if human relations are harmoniously maintained. The perfect teaching of Islam introduces to mankind the existence of itself as an individual being as well as a social being created by Allah Almighty. which is cultured. The ability of assimilation and adaptation to fellow human beings who are of different races, ethnic, language, religion, nation, culture etc., are influenced even by one's education. Adult guidance and direction to an immature child to recognize, understand, respect and respect others different from himself becomes a necessity in a plural society such as in the Unitary State of the Republic of Indonesia. The conscious effort of educators towards such learners is called multicultural education.
\end{abstract}

Keywords: Plural, Interaction, Multicultural Education.

\section{PENDAHULUAN}

\section{A. Latar Belakang Masalah}

llah swt. menciptakan manusia berjenis kelamin laki-laki dan perempuan,
berbangsa-bangsa dan bersuku-suku supaya berta'aruf, (Q.s. al-Hujurat/49:
13). Manusia dapat menjalani hidupnya dengan tenang dan tenteram apabila terjalin hubungan yang harmonis dengan sesama manusia yang ada di sekitarnya. Jalinan komunikasi akan mudah terbangun dan terpelihara jika memiliki kesamaan dalam berbagai aspek kehidupan. Akan tetapi, kalau hidup di tengah-tengah masyarakat majemuk/plural diperlukan adaptasi dan pembauran yang sistemik, sehingga toleransi, saling menghormati dan saling menghargai dapat terwujud.

Setiap anggota masyarakat seyogyanya hidup dalam tatanan kehidupan yang menjunjung tinggi pluralitas, toleransi, rasionalitas, keterbukaan, persamaan, taat aturan, menghargai orang lain, menerima perubahan, serta menjamin kemerdekaan berpikir, berbicara, dan berkreasi untuk mencapai kemajuan. Seiring dengan itu, setiap warga negara dituntut mempersempit kecenderungan eksklusivitas, intoleransi, sikap merasa benar sendiri, reaktif dalam merespon persoalan dan mengedepankan kekerasan dalam mengatasi masalah.

Kondisi masyarakat Indonesia yang sangat plural baik dari aspek suku, ras, agama serta status sosial memberikan kontribusi yang luar biasa terhadap perkembangan dan dinamika kehidupan masyarakat. Namun, kondisi yang demikian memungkinkan pula terjadinya benturan antar budaya, antar ras, etnik, agama dan nilai-nilai yang berlaku dalam masyarakat. Kasus Ambon, Sampit, Poso, Aceh, konflik antara FPI dan 
kelompok Achmadiyah, dan sebagainya telah menyadarkan kita bahwa kalau hal ini dibiarkan, maka sangat memungkinkan terjadinya disintegrasi bangsa. ${ }^{1}$

Tragedi kekerasan antarkelompok yang meledak secara sporadis di akhir tahun 1990-an di berbagai kawasan di Indonesia menunjukkan betapa rentannya rasa kebersamaan yang dibangun dalam Negara-Bangsa, betapa kentalnya prasangka antara kelompok dan betapa rendahnya nilai-nilai multikulturisme. ${ }^{2}$

Azyumardi Azra, dalam Muhaemin El-Ma'hady menyatakan bahwa pada level nasional, berakhirnya sentralisme kekuasan yang pada masa orde baru memaksakan "monokulturalisme" yang nyaris seragam, memunculkan reaksi balik, yang bukan tidak mengandung implikasi-implikasi negatif bagi rekonstruksi kebudayaan Indonesia yang multikultural. Berbarengan dengan proses otonomisasi dan desentralisasi kekuasaan pemerintahan, terjadi peningkatan gejala "provinsialisme" yang hampir tumpang tindih dengan "etnisitas". Kecenderungan ini, jika tidak terkendali akan dapat menimbulkan tidak hanya disintegrasi sosio-kultural yang amat parah, tetapi juga disintegrasi politik. ${ }^{3}$

Intensitas dan ekstensitas konflik sosial di tengah-tengah masyarakat terasa kian meningkat, terutama konflik sosial yang bersifat horisontal, yakni konflik yang berkembang di antara anggota masyarakat, meskipun tidak menutup kemungkinan timbulnya konflik berdimensi vertikal, yakni antara masyarakat dan negara.

Konflik sosial dalam masyarakat merupakan proses interaksi yang alamiah. Konflik itu menimbulkan persoalan jika konflik sosial yang berkembang dalam masyarakat tidak lagi menjadi sesuatu yang positif, tetapi berubah menjadi destruktif bahkan anarkis.

Indonesia sebagai bangsa yang pluralistik, memiliki suku bangsa, etnis, dan potensi budaya yang sangat banyak, dalam membangun masa depan bangsa dipandang perlu untuk memberi tempat dan hak bagi berkembangnya kebudayaan dari berbagai suku bangsa dan agama yang ada di Indonesia. Dalam kehidupan sehari-hari, kebudayaan suku bangsa dan agama, telah hidup bersama dengan berpedoman kepada norma-norma berbangsa dan bernegara, mewarnai perilaku dan kegiatan masyarakat. Berbagai kebudayaan jalan beriringan, saling melengkapi dan saling mengisi, tidak berdiri sendiri-sendiri, bahkan mampu untuk saling menyesuaikan dalam kehidupan sehari-hari. Intinya adalah menekankan pada pentingnya memberikan kesempatan bagi berkembangnya masyarakat multikultural yang masing-masing harus diakui haknya untuk mengembangkan dirinya.

Hal ini juga berarti bahwa masyarakat multikultural harus memperoleh kesempatan yang baik untuk menjaga dan mengembangkan kearifan budaya lokal

1 Pupu Saeful Rahmat. http://akhmadsudrajat.wordpress.com/2008/04/04/wacana-pendidikanmultikultural-di-indonesia/4 April 2008 by Akhmad Sudrajat. Diakses Mei 2012.

${ }^{2}$ Choirul Mahfud. Pendidikan Multikultural, (Cet. II; Yogyakarta: Pustaka Pelajar, 2008), h. xix.

${ }^{3}$ Muhaemin El-Ma'hady. Multikulturalisme dan Pendidikan Multikultural, http://researchengines. com/muhaemin6-04.html Diakses, 5 Mei 2012. 
mereka ke arah kualitas dan pendayagunaan yang lebih baik. Unsur-unsur budaya lokal yang bermanfaat bagi diri sendiri bahkan perlu dikembangkan lebih lanjut agar dapat menjadi bagian dari kebudayaan bangsa, karena akan memperkaya unsur-unsur kebudayaan nasional. Meskipun demikian, misi utamanya adalah mentransformasikan kenyataan multikultural sebagai aset dan sumber kekuatan bangsa serta menjadikannya suatu sinergi nasional.

Untuk mengetahui apakah sesuatu pengetahuan atau gagasan sudah menjadi kebudayaan suatu masyarakat, dapat dilihat dari sikap dan perilaku masyarakat itu sendiri dalam kehidupan mereka sehari-hari. ${ }^{4}$ Budaya sebagai sistem pemikiran mencakup sistem gagasan, konsep-konsep, aturan-aturan serta pemaknaan yang mendasari dan diwujudkan dalam kehidupan yang dimilikinya melalui proses belajar. ${ }^{5}$

Masyarakat multikultural harus dihargai potensi dan haknya untuk mengembangkan diri sebagai pendukung kebudayaannya, namun pada saat yang sama, mereka juga harus tetap diberi ruang dan kesempatan untuk mampu melihat dirinya, serta dilihat oleh masyarakat lainnya yang sama-sama merupakan warga negara Indonesia, sehingga setiap warga negara mendapatkan peluang dan kesempatan membangun dirinya, membangun tanah leluhurnya, yang berarti membangun bangsa dan tanah air tanpa merasakannya sebagai beban, tetapi karena ikatan kebersamaan dan saling bekerjasama, bahkan diharapkan dapat membangkitkan semangat dan kesadaran sebagai tanggung jawabnya.

Indonesia, sebagai negara berkembang mengalami krisis yang berkepanjangan. Krisis ekonomi, krisis sosial budaya, krisis moral yang dikuti dengan berbagai krisis lainnya, menyadarkan kita akan pentingnya modal sosial. Modal sosial merupakan energi kolektif masyarakat yang berupa kebersamaan, solidaritas, kerjasama, tolerasi, kepercayaan, dan tanggung jawab tiap anggota masyarakat dalam memainkan setiap peran yang diamanahkan. Bila energi kolektif hancur maka hancur pulalah keharmonisan, keseimbangan, keserasian, dan keselarasan dalam masyarakat.

Untuk itu, dipandang sangat penting memberikan porsi pendidikan multikultural dalam sistem pendidikan nasional agar peserta didik memiliki kepekaan dalam menghadapi gejala-gejala dan masalah-masalah sosial yang berakar pada perbedaan suku, ras, agama dan tata nilai yang terjadi pada lingkungan masyarakatnya. Hal ini dapat diimplementasikan baik pada substansi maupun model pembelajaran yang mengakui dan menghormati keanekaragaman budaya.

Menurut Sosiolog UI Parsudi Suparlan, yang dikutip oleh Pupu Saeful Rahmat, multikulturalisme adalah konsep yang mampu menjawab tantangan perubahan zaman; dengan alasan multikulturalisme merupakan sebuah idiologi yang mengagungkan

${ }^{4}$ Sjafri Sairin, Perubahan Sosial Masyarakat Indonesia: Perspektif Antropologi (Cet. I; Yogyakarta: Pustaka Pelajar, 2002), h. 2.

5 Hari Poerwanto, Kebudayaan dan Lingkungan: Dalam Perspektif Antropologi (Cet. II; Yogyakarta: Pustaka Pelajar, 2005), h. 58. 
perbedaan budaya, atau sebuah keyakinan yang mengakui dan mendorong terwujudnya pluralisme budaya sebagai corak kehidupan masyarakat. Multikulturalisme akan menjadi pengikat dan jembatan yang mengakomodasi perbedaan-perbedaan termasuk perbedaan kesukubangsaan, budaya, dan agama dalam masyarakat yang multikultural. Perbedaan itu dapat terwadahi di tempat-tempat umum, tempat kerja dan pasar, dan sistem nasional dalam hal kesetaraan derajat secara politik, hukum, ekonomi, dan sosial. $^{6}$

Sejarah menunjukkan, pemaknaan secara negatif atas keragaman telah melahirkan penderitaan panjang umat manusia. Pada awal tahun 2000-an, paling tidak telah terjadi 35 pertikaian besar antar etnis di dunia. Lebih dari 38 juta jiwa terusir dari tempat yang mereka diami, paling sedikit 7 juta orang terbunuh dalam konflik etnis berdarah. Pertikaian seperti ini terjadi dari Barat sampai Timur, dari Utara hingga Selatan. Dunia menyaksikan darah mengalir dari Yugoslavia, Cekoslakia, Zaire hingga Rwanda, dari bekas Uni Soviet sampai Sudan, dari Srilangka, India hingga Indonesia. Konflik panjang tersebut melibatkan sentimen etnis, ras, golongan dan juga agama. ${ }^{7}$

Berdasar gambaran di atas, maka dalam tulisan ini akan dibahas tentang pendidikan multikultural yang dinamis dan Islami, dalam arti, dengan melalui pendidikan perbedaan-perbedaan alamiah yang telah menjadi kultur dalam masyarakat tidak akan menjadi pemicu terjadinya konflik dalam masyarakat, akan tetapi tetap tumbuh dan berkembang ke arah yang lebih baik berdasarkan norma-norma agama yang dianut, khususnya norma agama Islam.

\section{B. Rumusan masalah}

Berdasarkan latar belakang di atas dapat dirumuskan masalah pokok tulisan ini yakni bagaimana bentuk dan peran pendidikan yang dapat menciptakan toleransi di kalangan masyarakat yang plural. Pokok masalah tersebut dikembangkan menjadi submasalah sebagai berikut:

1. Bagaimana Peran Pendidikan dalam Masyarakat Plural?

2. Bagaimana Pandangan Islam tentang Pendidikan Multikultural?

\section{PEMBAHASAN}

\section{A. Peranan Pendidikan dalam Masyarakat Plural}

Menurut James. A. Banks Pendidikan multikultural adalah konsep, ide atau falsafah sebagai suatu rangkaian kepercayaan (set of believe) dan penjelasan yang mengakui dan menilai pentingnya keragaman budaya dan etnis di dalam membentuk gaya hidup, pengalaman sosial, identitas pribadi kesempatan-kesempatan pendidikan dari individu, kelompok, maupun negara.

6 Pupu Saeful Rahmat. http://akhmadsudrajat.wordpress.com/2008/04/04/wacana-pendidikanmultikultural-di-indonesia/4 April 2008 by Akhmad Sudrajat. Diakses Mei 2012.

${ }^{7}$ Muhaemin El-Ma'hady. Multikulturalisme dan Pendidikan Multikultural, http://researchengines. com/muhaemin6-04.html Diakses, 5 Mei 2012. 
James Banks (1994) menjelaskan bahwa pendidikan multikultural memiliki beberapa dimensi yang saling berkaitan satu dengan yang lain, yaitu: Pertama, mengintegrasikan berbagai budaya dan kelompok untuk mengilustrasikan konsep mendasar, generalisasi dan teori dalam mata pelajaran/disiplin ilmu. Kedua, membawa siswa untuk memahami implikasi budaya ke dalam sebuah mata pelajaran (disiplin). Ketiga, menyesuaikan metode pengajaran dengan cara belajar siswa dalam rangka memfasilitasi prestasi akademik siswa yang beragam baik dari segi ras, budaya (culture) ataupun sosial. Keempat mengidentifikasi karakteristik ras siswa dan menentukan metode pengajaran mereka. Kemudian melatih kelompok-kelompok untuk berpartisipasi dalam kegiatan olah raga, berinteraksi dengan seluruh staff dan siswa yang berbeda etnis dan ras dalam upaya menciptakan budaya akademik yang toleran dan inklusif. ${ }^{8}$

Wacana multikulturalisme di Indonesia menemukan momentumnya ketika sistem nasional yang otoriter-militeristik tumbang seiring dengan jatuhnya rezim Soeharto. Saat itu, keadaan negara menjadi kacau balau dengan berbagai konflik antarsuku bangsa dan antar golongan, yang menimbulkan keterkejutan dan kengerian para anggota masyarakat. Kondisi yang demikian membuat berbagai pihak semakin mempertanyakan kembali sistem nasional seperti apa yang cocok bagi Indonesia yang sedang berubah, serta sistem apa yang bisa membuat masyarakat Indonesia bisa hidup damai dengan meminimalisir potensi konflik.

Era reformasi ternyata tidak hanya membawa berkah bagi bangsa kita namun juga memberi peluang meningkatnya kecenderungan primordialisme. Untuk itu, dirasakan perlunya menerapkan paradigma pendidikan multikultur untuk menangkal semangat primordialisme tersebut.

Paradigma pendidikan multikulturalisme sangat bermanfaat untuk membangun kohesifitas, soliditas dan intimitas di antara keragamannya etnik, ras, agama, budaya dan kebutuhan di antara kita. Paparan di atas juga memberi dorongan dan spirit bagi lembaga pendidikan nasional untuk mau menanamkan sikap kepada peserta didik untuk menghargai orang, budaya, agama, dan keyakinan lain. Harapannya, dengan implementasi pendidikan yang berwawasan multikultural, akan membantu siswa mengerti, menerima dan menghargai orang lain yang berbeda suku, budaya dan nilai kepribadian.

Pupu Saeful Rahmat menyebutkan lebih lanjut bahwa penanaman semangat multikul-turalisme di sekolah-sekolah, akan menjadi medium pelatihan dan penyadaran bagi generasi muda untuk menerima perbedaan budaya, agama, ras, etnis dan kebutuhan di antara sesama dan mau hidup bersama secara damai. Agar proses ini berjalan sesuai harapan, maka seyogyanya kita mau menerima jika pendidikan multikultural disosialisasikan dan didesiminasikan melalui lembaga pendidikan, serta ditetapkan sebagai bagian dari kurikulum pendidikan di berbagai jenjang dan jalur pendidikan.

${ }^{8}$ Choirul Mahfud. Pendidikan Multikultural, (Cet. II; Yogyakarta: Pustaka Pelajar, 2008), h. 177178. 
Apalagi, paradigma multikultural secara implisit juga menjadi salah satu concern dari Pasal 4 UU N0. 20 Tahun 2003 Sistem Pendidikan Nasional. Dalam pasal itu dijelaskan, bahwa pendidikan diselenggarakan secara demokratis, tidak diskriminatif dengan menjunjung tinggi HAM, nilai keagamaan, nilai kultural dan kemajemukan bangsa. ${ }^{9}$

Tujuan utama dari pendidikan multikultural adalah untuk menanamkan sikap simpati, respek, apresiasi, dan empati terhadap penganut agama dan budaya yang berbeda. Lebih jauh lagi, penganut agama dan budaya yang berbeda dapat belajar untuk melawan atau setidaknya tidak setuju dengan ketidak-toleranan, perang agama, diskriminasi, dan hegemoni budaya di tengah kultur monolitik dan uniformitas global.

Ide pendidikan multikulturalisme dijadikan komitmen global sebagaimana direkomendasi UNESCO pada bulan Oktober 1994 di Jenewa. Rekomendasi itu di antaranya memuat empat pesan. Pertama, pendidikan hendaknya mengembangkan kemampuan untuk mengakui dan menerima nilai-nilai yang ada dalam kebhinekaan pribadi, jenis kelamin, masyarakat dan budaya serta mengembangkan kemampuan untuk berkomunikasi, berbagi dan bekerja sama dengan yang lain. Kedua, pendidikan hendaknya meneguhkan jati diri dan mendorong konvergensi gagasan dan penyelesaianpenyelesaian yang memperkokoh perdamaian, persaudaraan dan solidaritas antara pribadi dan masyarakat. Ketiga, pendidikan hendaknya meningkatkan kemampuan menyelesaikan konflik secara damai dan tanpa kekerasan. Karena itu, pendidikan hendaknya juga meningkatkan pengembangan kedamaian dalam diri dan pikiran peserta didik sehingga dengan demikian mereka mampu membangun secara lebih kokoh kualitas toleransi, kesabaran, kemauan untuk berbagi dan memelihara. ${ }^{10}$

Secara generik, pendidikan multikultural memang sebuah konsep yang dibuat dengan tujuan untuk menciptakan persamaan peluang pendidikan bagi semua siswa yang berbeda-beda ras, etnis, kelas sosial dan kelompok budaya. Salah satu tujuan penting dari konsep pendidikan multikultural adalah untuk membantu semua siswa agar memperoleh pengetahuan, sikap dan ketrampilan yang diperlukan dalam menjalankan peran-peran seefektif mungkin pada masyarakat demokrasi-pluralistik serta diperlukan untuk berinteraksi, negosiasi, dan komunikasi dengan warga dari kelompok beragam agar tercipta sebuah tatanan masyarakat bermoral yang berjalan untuk kebaikan bersama.

Gelombang demokrasi menuntut pengakuan perbedaan dalam tubuh bangsa Indonesia yang majemuk. Oleh sebab itu, pendidikan multikultural adalah jawaban atas beberapa problematika kemajemukan itu. Perlu disadari bahwa proses pendidikan

9 Pupu Saeful Rahmat. http://akhmadsudrajat.wordpress.com/2008/04/04/wacana-pendidikanmultikultural-di-indonesia/4 April 2008 by Akhmad Sudrajat. Diakses Mei 2012.

10 Pupu Saeful Rahmat. http://akhmadsudrajat.wordpress.com/2008/04/04/wacana-pendidikanmultikultural-di-indonesia/4 April 2008 by Akhmad Sudrajat. Diakses Mei 2012. 
adalah proses pembudayaan dan cita-cita persatuan bangsa merupakan unsur budaya bangsa. ${ }^{11}$

Pendidikan multikultural mencerminkan keseimbangan antara pemahaman persamaan dan perbedaan budaya serta mendorong individu untuk mempertahankan dan memperluas wawasan budaya dan kebudayaan mereka sendiri.

Aspek-aspek yang menjadi kunci dalam melaksanakan pendidikan multikultural di lingkungan sekolah adalah tidak adanya kebijakan yang menghambat toleransi, termasuk tidak adanya penghinaan terhadap ras, etnis dan jenis kelamin. Juga, harus menumbuhkan kepekaan terhadap perbedaan budaya, di antaranya mencakup pakaian, musik dan makanan kesukaan. Selain itu, juga memberikan kebebasan bagi anak dalam merayakan hari-hari besar umat beragama serta memperkokoh sikap anak agar merasa butuh terlibat dalam pengambilan keputusan secara demokratis. ${ }^{12}$

Implementasi pendidikan multikultural tidak akan lepas dari konsep-konsep pembaharuan pendidikan, karena pembaharuan pendidikan mempunyai konsep konstruktif yang membentuk terwujudnya pendidikan multikultural. Menurut Hujair A.H. Sanaky (2003:157), dalam melakukan pembaharuan, pendidikan diharapkan mengorientasikan tujuannya lebih bersifat problematis, strategis, aspiratif, menyentuh aspek aplikasi, serta dapat merespon kebutuhan masyarakat. Kemudian dari kerangka ini, tujuan yang dirumuskan meliputi aspek ilahiyyah (teoritis), fisik dan intelektual, kebebasan (liberal), akhlak, profesionalisme, berkualitas, dinamis, dan kreatif sebagai insan kamil dalam kehidupannya. ${ }^{13}$

Kebijakan yang sentralistis dan pengawalan yang ketat terhadap isu perbedaan telah menghilangkan kemampuan masyarakat untuk memikirkan, membicarakan dan memecahkan persoalan yang muncul dari perbedaan secara terbuka, rasional dan damai. Pendidikan multikultural sangat penting diterapkan guna meminimalisasi dan mencegah terjadinya konflik di beberapa daerah. Melalui pendidikan berbasis multikultural, sikap dan pemikiran (mindset) siswa akan lebih terbuka untuk memahami dan menghargai keberagaman.

Dengan pengembangan model pendidikan berbasis multikultural diharapkan mampu menjadi salah satu metode efektif meredam konflik. Selain itu, pendidikan multikultural bisa menanamkan sekaligus mengubah pemikiran peserta didik untuk benar-benar tulus menghargai keberagaman etnis, agama, ras, dan antargolongan, toleransi merupakan sikap warga yang aktif, bukan sikap yang spontan. Artinya sikap

11 Syafiq A. Mughni, Pendidikan Berbasis Multikulturisme dalam Choiril Mahfud, Pendidikan Multikulturisme (Cet. II; Yogyakarta: Pustaka Pelajar, 2008), h. viii.

12 Pupu Saeful Rahmat. http://akhmadsudrajat.wordpress.com/2008/04/04/wacana-pendidikanmultikultural-di-indonesia/4 April 2008 by Akhmad Sudrajat. Diakses Mei 2012.

13 http://sawali.info/2011/03/08/implementasi-pendidikan-multikultural-di-sekolah. Diakses, Mei 2012. 
toleran tidak akan tertanam dengan sendirinya, tanpa ada usaha sadar mengintegrasikannya dalam pendidikan. ${ }^{14}$

Dari serangkaian implementasi program pengembangan model pendidikan multikultural di Madrasah Pembangunan UIN bisa diketahui beberapa pencapaian indikator pembelajaran, di antaranya, adanya pemahaman dan afeksi siswa tentang nilainilai multikultural yang dikembangkan. Misalnya, toleransi, solidaritas, musyawarah, dan pengungkapan diri.

Sugiono menerangkan bahwa metodologi dan strategi pembelajaran multikultural dengan menggunakan sarana audio visual telah cukup menarik minat belajar anak serta sangat menyenangkan bagi siswa dan guru. Karenanya, siswa sekaligus dapat mendengar, melihat, dan melakukan praktik selama proses pembelajaran berlangsung.

Sugiono menambahkan, program pendidikan multikultural dalam penerapannya saat ini bukanlah mata pelajaran yang berdiri sendiri, namun terintegrasi ke dalam matamata pelajaran, sehingga dalam implementasinya perlu dilakukan oleh guru-guru yang kreatif dan inovatif. "Guru-guru dituntut kreatif dan inovatif sehingga mampu mengolah dan menciptakan desain pembelajaran yang sesuai. Termasuk memberikan dan membangkitkan motivasi belajar."

Kepala Proyek Pengembangan Model Pendidikan Multikultural untuk Anak Usia Sekolah PKPM Unika Atma Jaya Jakarta Muniarti Agustina menjelaskan, melalui model pembelajaran berbasis multikultural, siswa diperkenalkan dan diajak megembangkan nilai-nilai dan sikap toleransi, solidaritas, empati, musyawarah, dan egaliter. "Dengan begini, siswa juga memahami kearifan lokal yang merupakan bagian dari budaya bangsa ini. Dan ini bisa menghambat terjadinya konflik."15

Dalam menggagas model ini, Muniarti memaparkan, PKPM Unika Atma Jaya Jakarta melakukan penelitian di 8 sekolah, antara lain, SDN Sunter Agung 03 Pagi, SDN Lebak Bulus 06, SD Andreas, Madrasah Pembangunan UIN Tangerang, dan SD Amanda (SD berbasis agama Budha).

Dikatakan, model pembelajaran multikultural ini bisa berhasil, jika kepala sekolah mendukung program ini. Selain itu, para pengajar juga mau menerima pembaruan dan sekolah sudah terbiasa mengembangkan kurikulum sendiri di samping kurikulum dari Departemen Pendidikan Nasional. "Sementara, alat lain yang mendukung adalah adanya audio visual. Karena ini menjadi penting untuk menyaksikan film-film bertema multikultural.

Menurut Tilaar krisis dewasa ini yang menonjol, yaitu: (1) bahwa pendidikan tidak terlepas dari keseluruhan hidup manusia di dalam segala aspeknya yaitu politik, ekonomi, hukum dan kebudayaan (2) krisis yang dialami oleh bangsa Indonesia dewasa

${ }^{14}$ Abd. Moqsith Ghazali, Argumen Pluralisme Agama: Membangun Toleransi Berbasis Alquran (Cet. II; Jakarta: KataKita, 2009), h. 226.

15 http://www.atmajaya.ac.id/content.asp?f=0\&id=3197. Pendidikan Multikultural Tanamkan Sikap Menghargai Keberagaman. Diakses Mei 2012. 
ini merupakan refleksi dari krisis pendidikan nasional. Krisis multi dimensi yang dialami oleh bangsa Indonesia tersebut, perlu diatasi dengan upaya-upaya terencana dan terarah menuju perubahan yang konstruktif. Oleh karena itu, fungsi pendidikan yang efektif menjadi signifikan dalam menuju perubahan atau dinamika sosial. ${ }^{16}$

Di sinilah terletak dilema klasik. Pendidikan merupakan akses yang sangat penting - jika tidak satu satunya - untuk mencapai mobilitas sosial, tetapi kaum miskin tidak dapat menjangkau akses tersebut, karena mahalnya biaya. Akhirnya terciptalah vicious circle (lingkaran setan); kemiskinan menciptakan keterbelakangan pendidikan, dan sosial ekonomi, dan keterbelakangan pendidikan menghasilkan kebodohan dan kemiskinan.

Anak-anak yang berasal dari keluarga miskin atau keluarga berantakan (broken home) dengan terpaksa mencari sendiri penghasilan di jalanan; menimbulkan kekhawatiran para pendidik dan orang tua, sebab mereka akan terbentuk kepribadian dan krakter yang dikembangkannya dalam kehidupan empirik. Mereka sebenarnya adalah komunitas anak yang telah kehilangan sebagian besar masa depan mereka dan mengalami tekanan hidup, sehingga mereka telah melarikan diri dari dunia nyata dan menikmati mimpi-mimpi tak sehat dengan cara menghisap lem karet yang mereka sebut sebagai ngelem. $^{17}$

Dalam konteks terakhir inilah kebutuhan pada kedermawanan (filantrofi) secara khusus untuk pendidikan terasa semakin dibutuhkan dan mendesak. Jika tidak, sekolah/madrasah yang berkualitas hanya bisa dimasuki anak-anak dari keluarga kaya. Padahal, kita juga tahu, terdapat cukup banyak anak dari kalangan miskin yang cerdas, berbakat, rajin, mau bekerja keras dan dengan demikian, cukup menjanjikan.

Apabila pendidikan relevan dengan kebutuhan masyarakat dan bermutu tinggi, maka pendidikan menjadi instrumen yang ampuh dalam menciptakan mobilitas sosial, atau dinamika sosial. Oleh karena itu, maju dan mundurnya suatu masyarakat dan bangsa sangat tergantung pada pelaksanaan sistem pendidikannya. Itu artinya proses sosial atau dinamika sosial secara sistematis dipengaruhi oleh pelaksanaan pendidikan di tengah-tengah masyarakat. Fenomena itu terbukti dari, krisis ekonomi, politik, krisis hukum dan krisis kebudayaan, termasuk krisis pendidikan.

Nilai-nilai yang diajarkan orang tua dan guru kepada anak-anak, akan berpengaruh secara efektif atau tidak, hanya kalau nilai-nilai tersebut dibagi oleh anak tersebut dengan yang lain. Di sinilah pentingnya guru-guru maupun orang tua harus bersiap menyeleksi nilai-nilai yang akan ditransformasikan atau dikesampingkan. Mengubah seseorang adalah dengan mengubah interaksinya, dunia sosialnya, kelompok

${ }^{16}$ H.A.R. Tilaar. Perubahan Sosial dan Pendidikan: Pengantar Pedagogik Transformatif untuk Indonesia, (Jakarta, Grasindo, 2002), h.

${ }^{17}$ Agus Salim, Pengantar Sosiologi Mikro (Cet. I; Yogyakarta: Pustaka Pelajar, 2008), h. 193. 
referensi, dan persepsinya, sebab dengan demikian, hal itu akan mengubah definisi diri dan situasi orang tersebut. ${ }^{18}$

Sekolah berfungsi sebagai sarana sosialisasi anak, selain keluarga dan lembagalembaga sosial lain yang ada di masyarakat. Proses sosialisasi anak di sekolah akan menentukan cara berpikir dan berperilaku yang sesuai dengan norma-norma yang diyakini dan dimiliki masyarakatnya. Kepribadian anak akan terbentuk sesuai dengan akar budayanya.

Fungsi pendidikan bagi suatu masyarakat dan bangsa adalah bahwa peradabanperadaban besar yang pernah dikenal dalam sejarah mengalami kehancuran sebagai akibat dari kegagalan pendidikan dalam menjalankan fungsinya. Secara esensial, manusia sebagai pribadi atau sebagai anggota masyarakat dan bangsa senantiasa mengalami perkembangan. Aktivitas manusia mewariskan dan mengembangkan kebudayaan itu terutama dilaksanakan melalui pendidikan dan latihan. Untuk itu, pendidikan dilihat sebagai proses sedangkan kebudayaan adalah isi pendidikan. Hal itu dimaksudkan agar tercapai tujuan yakni meningkatkan perkembangan sosio-budaya bahkan martabat bangsa, kewibawaan dan kejayaan negara.

Pendidikan pada hakikatnya merupakan sarana untuk mengantarkan peserta didik menuju pada kesadaran sosial yang lebih tinggi dari sebelum ia mengenyam pendidikan. Namun, terkadang dalam pelaksanaan pendidikan justru memisahkan peserta didik dari kehidupan sosialnya. Hal ini terjadi bila pendidikan yang diberikan bukan lagi berbasis pada realitas masyarakat. Akan tetapi, lebih berorientasi pada pemenuhan kebutuhan pasar. Peserta didik setelah selesai mendapatkan pendidikan bukan peka akan realitas sosial malah hilang dari realitas sosial.

Pendidikan multikultural tidak cukup menjadi tanggung jawab guru mata pelajaran tertentu, tetapi perlu diimplementasikan secara integral ke dalam berbagai materi pembelajaran yang relevan dengan mata pelajaran yang bersangkutan. Tidak ada salahnya, peserta didik diajak berdialog dan belajar menumbuhkan kepekaannya terhadap kasus kekerasan yang terjadi. Bagaimana respon dan sikap peserta didik terhadap aksi-aksi kekerasan yang terjadi bisa dijadikan sebagai masukan berharga dalam proses pembelajaran berbasis pendidikan multikultural. Guru perlu memberikan kebebasan kepada subjek didik untuk merespon dan menyikapinya, sehingga mereka merasa dihargai dan diperlakukan sebagai sosok yang amat dibutuhkan kehadirannya dalam proses pembelajaran.

Meskipun demikian, guru dalam fungsinya sebagai fasilitator dan mediator pembelajaran perlu memberikan penguatan agar pengalaman belajar yang mereka peroleh bisa dikonstruksi menjadi pengetahuan baru tentang nilai-nilai multikultural itu. Jika dikemas dalam proses pembelajaran yang menarik dan menyenangkan, bukan mustahil kelak mereka akan menjadi generasi yang "sadar budaya" sehingga mampu

${ }^{18}$ R. Riyadi Soeprapto, Interaksionisme Simbolik: Perspektif Sosiologi Modern (Cet. I; Malang: Averroes Press, 2002), h. 187. 
menyandingkan keberagaman sebagai kekayaan budaya bangsa yang perlu dihormati dengan sikap toleran, tulus, dan jujur.

\section{B. Pandangan Islam tentang Pendidikan Multikultural}

Arifin Assegaf mengemukakan ungkapan yang sangat terkenal dari filosof sekaligus seorang teolog, Hans Küng yang diterjemahkan dari Bahasa Inggris "Tiada ada perdamaian di antara agama-agama tanpa dialog di antara agama-agama; tiada dialog-dialog jika tidak mempelajari fondasi agama-agama". ${ }^{19}$ Selanjutnya dinyatakan bahwa tindakan saling membunuh yang tampaknya tak akan berkesudahan antara golongan Muslim, Yahudi, Kristen di Palestina; bentrokan berdarah antara golongan Katolik dan Protestan di Irlandia Utara serta kekejaman tak berperikemanusiaan di Bosnia antara Kristen ortodoks, Katolik dan Muslim, adalah akibat dari mengabaikan ungkapan Hans Küng tersebut. Padahal semua agama mengajarkan kedamaian dan setiap pemeluk agama mendambakan/mengharapkan kerukunan hidup dan kehidupan.

Pada prinsipnya, pendidikan multikultural adalah pendidikan yang menghargai perbedaan. Pendidikan multikultural senantiasa menciptakan struktur dan proses di mana setiap kebudayaan bisa melakukan ekspresi. Ada dua hal yang perlu diperhatikan untuk mewujudkan pendidikan multikultural, yakni: pertama, adalah dialog. Pendidikan multikultural tidak mungkin berlansung tanpa dialog. Dalam pendidikan multikultural, setiap peradaban dan kebudayaan yang ada berada dalam posisi yang sejajar dan sama. Dialog meniscayakan adanya persamaan dan persamaan di antara pihak-pihak yang terlibat. Dengan dialog, diharapkan terjadi sumbang pemikiran yang pada gilirannya akan memperkaya kebudayaan atau peradaban yang bersangkutan. Kedua adalah toleransi. Toleransi adalah sikap menerima bahwa orang lain berbeda dengan kita. Dialog dan toleransi merupakan satu kesatuan yang tidak dapat dipisahkan. Bila dialog itu bentuknya, toleransi itu isinya. Toleransi diperlukan bukan hanya pada tataran konseptual, melainkan juga pada tingkat teknis operasional. Sistem pendidikan kita selama ini terlalu menitikberatkan pada pengayaan pengetahuan dan keterampilan tetapi mengabaikan penghargaan atas nilai-nilai budaya dan tradisi bangsa. ${ }^{20}$

Bangsa Indonesia saat ini dihadapkan pada perubahan sosial yang sangat kompleks akibat globalisasi dan modernisasi tahap lanjut. Budaya hidup instan mewarnai sebagian masyarakat Indonesia. Kehidupan sosial budaya mengalami perubahan sosial yang kapitalistik, sehingga hampir semua aspek dikomersialkan termasuk menjualbelikan anak-anak dan organ tubuh manusia layaknya barang dagangan di pasar bebas. Bangsa Indonesia yang terkenal sebagai masyarakat religius, tidak boleh dibiarkan berwatak sekuler dan serba bebas. Dalam konteks inilah

${ }^{19}$ Arifin Assegaf. Memahami Sumber Konflik Antar Iman; dalam Th. Sumartana, dkk. Pluralisme, Konflik dan Pendidikan Agama di Indonesia (Yogyakarta: Pustaka Pelajar, 2001), h. 38.

20 Syafiq A. Mughni, Pendidikan Berbasis Multikulturisme dalam Choiril Mahfud, Pendidikan Multikulturisme (Cet. II; Yogyakarta: Pustaka Pelajar, 2008), h. xiv. 
pentingnya pendidikan multikultural untuk membangun karakter keadaban yang Islami atau religius.

Masyarakat Islami antara lain ditandai dengan upaya mempertahankan dan menjunjung tinggi nilai-nilai keadaban yang luhur. Keadaban adalah bagian dari kebudayaan yang menunjukkan orientasi perilaku kolektif dalam relasi sosial masyarakat berdasarkan ajaran moral yang bersumber dari agama yang dianutnya.

Wawasan pluralis-multikultural dalam pendidikan agama merupakan bekal penting agar kalangan terpelajar dan masyarakat luas menghargai perbedaan, menghormati secara tulus, komunikatif, terbuka, dan tidak saling curiga, selain untuk meningkatkan iman dan taqwa. Pendidikan pluralis bukunlah mengajarkan anak didik untuk menjalankan agama dengan seenaknya sendiri, tanpa tanggung jawab dan ketulusan, tetapi justru mengajarkan untuk taat beragama, tanpa menghilangkan identitas keagamaan masing-masing. Wajah agama yang ditampilkan pendidikan pluralis adalah agama yang moderat dan ramah. ${ }^{21}$

Pendidikan pluralis-multikultural adalah proses penyadaran yang berwawasan pluralis (secara agama) dan sekaligus berwawasan multikultural (secara budaya). Pendidikan pluralis-multikultural harus dilihat sebagai bagian dari usaha komprehensif menghindari, mencegah, dan menanggulangi konflik bernuansa etnis dan agama di masa mendatang. ${ }^{22}$

Pendidikan multikultural mempunyai beberapa karakteristik dalam pengimplementasiannya. Menurut Zakiyyudin Baidhawy (2005:78), karekteristik dari pendidikan multikultural tersebut meliputi tujuh komponen, yaitu belajar hidup dalam perbedaan, membangun tiga aspek mutual (saling percaya, saling pengertian, dan saling menghargai), terbuka dalam berfikir, apresiasi dan interdependensi, serta resolusi konflik dan rekonsiliasi nirkekerasan. Kemudian dari karakteristik-karakteristik tersebut, diformulasikan dengan ayat-ayat Alquran sebagai back up strategis (baca:dalil), bahwa konsep pendidikan multikultural ternyata selaras dengan ajaranajaran Islam dalam mengatur tatanan hidup manusia di muka bumi ini, terutama sekali dalam konteks pendidikan. ${ }^{23}$ Pandangan tersebut didasarkan pada:

Pertama; karakteristik belajar hidup dalam perbedaan. Selama ini pendidikan lebih diorientasikan pada tiga pilar pendidikan, yaitu menambah pengetahuan, pembekalan keterampilan hidup (life skill), dan menekankan cara menjadi “orang" sesuai dengan kerangka berfikir peserta didik. Kemudian dalam realitas kehidupan yang plural, ketiga pilar tersebut kurang mumpuni dalam menjawab relevansi masyarakat

21 Muhammad Ali, Teologi pluralis-multikultural: Menghargai Kemajemukan Menjalin Kebersamaan (Jakarta: Kompas, 2003), h. 102.

22 Muhammad Ali, Teologi pluralis-multikultural: Menghargai Kemajemukan Menjalin Kebersamaan (Jakarta: Kompas, 2003), h. 99-100.

23 Andipostra dan Andi Sugiharta. http://id.shvoong.com/social-sciences/1918568-pendidikanmultikultural. diakses 6 Mei 2012. 
yang semakin majemuk. Maka dari itu diperlukan satu pilar strategis yaitu belajar saling menghargai akan perbedaan, sehingga akan terbangun relasi antarpersonal dan interpersonal. Dalam terminology Islam, realitas akan perbedaan tak dapat dipungkiri lagi, sesuai dengan Q.s. al-Hujurat/49: 13 yang menekankan bahwa Allah swt. menciptakan manusia yang terdiri dari jenis kelamin yang berbeda, berbagai suku, bangsa, serta interprestasi yang berbeda-beda. Hal ini juga dipertegas dengan sikap Nabi saw. yang berdiam diri sebagai bentuk persetujuan beliau, ketika ada dua sahabatnya yang berbeda pendapat dalam suatu ketentuan hukum.

Kedua; membangun tiga aspek mutual, yaitu membangun saling percaya (mutual trust), memahami saling pengertian (mutual understanding), dan menjunjung sikap saling menghargai (mutual respect). Tiga hal ini sebagai konsekuensi logis akan kemajemukan dan kehegemonian, maka diperlukan pendidikan yang berorientasi kepada kebersamaan dan penanaman sikap toleran, demokratis, serta kesetaraan hak. Banyak ayat Alquran yang menekankan akan pentingnya saling percaya, pengertian, dan menghargai orang lain, di antaranya ayat yang menganjurkan untuk menjauhi berburuk sangka dan mencari-cari kesalahan orang lain (Q.s. al-Hujurat/49: 12), tidak langsung memvonis dan selalu mengedepankan klarifikasi (Q.s. al-Hujurat/49: 6), serta ayat yang menegaskan prinsip tidak ada paksaan dalam memeluk agama tertentu (Q.s. al-Baqarah/2: 256). Kebebasan beragama dan respek terhadap kepercayaan orang lain bukan hanya penting bagi masyarakat majemuk, tetapi bagi orang Islam, hal tersebut merupakan ajaran Alquran. Membela kebebasan beragama dan menghormati kepercayaan orang lain merupakan bagian dari kemusliman. ${ }^{24}$

Ketiga; terbuka dalam berfikir. Pendidikan seyogyanya memberi pengetahuan baru tentang bagaimana berfikir dan bertindak, bahkan mengadopsi dan beradaptasi terhadap kultur baru yang berbeda, kemudian direspons dengan fikiran terbuka dan tidak terkesan eksklusif. Peserta didik didorong untuk mengembangkan kemampuan berfikir sehingga tidak ada kejumudan dan keterkekangan dalam berfikir. Penghargaan Alquran terhadap mereka yang mempergunakan akal, bisa dijadikan bukti representatif bahwa konsep ajaran Islampun sangat responsif terhadap konsep berfikir secara terbuka. Salah satunya ayat yang menerangkan betapa tingginya derajat orang yang berilmu (Q.s. al-Mujadallah/58: 11), dan ayat yang menjelaskan bahwa Islam tidak mengenal kejumudan dan dogmatisme (Q.s. al-Baqarah/2: 170).

Keempat; apresiasi dan interdependensi. Karakteristik ini mengedepankan tatanan kepedulian (social care), yakni semua anggota masyarakat dapat saling menunjukan apresiasi dan memelihara relasi, keterikatan, kohesi, dan keterkaitan sosial yang rekat, karena bagaimanapun juga manusia tidak bisa survive tanpa ikatan sosial yang dinamis. Konsep seperti ini banyak termaktub dalam Alquran, salah satunya Q.s. al-Maidah/5: 2 yang menerangkan betapa pentingnya prinsip tolong menolong dalam kebajikan,

${ }^{24}$ Abd. Moqsith Ghazali, Argumen Pluralisme Agama: Membangun Toleransi Berbasis Alquran (Cet. II; Jakarta: KataKita, 2009), h. 226. 
memelihara solidaritas dan ikatan sosial (takwa), dengan menghindari tolong menolong dalam kejahatan.

Kelima; resolusi konflik dan rekonsiliasi nirkekerasan. Konflik dalam berbagai hal harus dihindari, dan pendidikan harus mengfungsikan diri sebagai satu cara dalam resolusi konflik. Adapun resolusi konflik belum cukup tanpa rekonsiliasi, yakni upaya perdamaian melalui sarana pengampunan atau memaafkan (forgiveness). Pemberian ampun atau maaf dalam rekonsiliasi adalah tindakan tepat dalam situasi konflik komunal. Dalam ajaran Islam, seluruh umat manusia harus mengedepankan perdamaian, cinta damai dan rasa aman bagi seluruh makhluk (Q.s. asy-Syura/42: 40), dan secara tegas Alquran juga menganjurkan untuk memberi maaf, membimbing ke arah kesepakatan damai dengan cara musyawarah, duduk satu meja dengan prinsip kasih sayang (Q.s. Ali Imran/3: 139).

Berangkat dari pemahaman karakteristik di atas, masih menurut Zakiyyudin Baidhawy (2005:85), pendidikan multikultural adalah gerakan pembaharuan dan inovasi pendidikan dalam rangka menanamkan kesadaran pentingnya hidup bersama dalam keragaman dan perbedaan, dengan spirit kesetaraan dan kesederajatan, saling percaya, saling memahami dan menghargai persamaan, perbedaan dan keunikan agama-agama, sehingga terjalin suatu relasi dan interdependensi dalam situasi saling mendengar dan menerima perbedaan pendapat dalam pikiran terbuka, untuk menemukan jalan terbaik mengatasi konflik dan menciptakan perdamaian melalui kasih sayang antar sesama.

Arifin Assegaf menyimpulkan bahwa jelas bagi kita semua bahwa Islam yang benar adalah agama yang tidak menutup diri, mengajak kepada keterbukaan, menganut prinsip kebebasan dengan penuh toleransi. Dengan kata lain, Islam berkewajiban tegasnya kaum muslimin berkewajiban untuk mempertahankan tradisi pluralisme. ${ }^{25}$

Berdasarkan makna-makna ayat Alquran tersebut di atas, dapat dipahami bahwa keberagaman/kemajemukan sudah merupakan sunnatullah, sehingga perbedaanperbedaan tidak akan mungkin dapat dihindari, tetapi harus dipahami dan disikapi secara tepat dan arif atas dasar persamaan dan kesetaraan menurut petunjuk-petunjuk ayat-ayat Alquran dan praktik hidup Rasulullah saw dalam berdampingan dengan masyarakat Madani yang plural, sehingga tatanan kehidupan masyarakat yang harmonis dan saling menghargai dapat terwujud.

\section{PENUTUP}

\section{A. Kesimpulan}

1. Pendidikan multikultural dapat diimplementasikan di Indonesia, baik melalui pendidikan formal, informal, maupun nonformal. Dalam pendidikan formal, dapat diintegrasikan dalam sistem pendidikan melalui kurikulum mulai PAUD, SD, SLTP, SLTA maupun di Perguruan Tinggi. Pendidikan multikultural tidak harus

${ }^{25}$ Arifin Assegaf. Memahami Sumber Konflik Antar Iman; dalam Th. Sumartana, dkk. Pluralisme, Konflik dan Pendidikan Agama di Indonesia (Yogyakarta: Pustaka Pelajar, 2001), h. 42. 
dirancang khusus sebagai materi pelajaran tersendiri, namun dapat diintegrasikan dalam kurikulum yang sudah ada melalui bahan ajar atau model pembelajaran yang relevan. Di Perguruan Tinggi misalnya, dapat diintegrasikan dalam kurikulum yang berperspektif multikultural, misalnya melalui mata kuliah umum seperti Kewarganegaraan, ISBD, Agama dan Bahasa. Demikian juga pada tingkat sekolah Usia Dini dapat diintegrasikan dalam kurikulum pendidikan misalnya dalam Out Bond Program. Pada tingkat SD, SLTP dan SLTA pendidikan multikultural ini dapat diintegrasikan dalam bahan ajar seperti PKn, Agama, Sosiologi, Antropologi, dan dapat melalui model pembelajaran yang lain seperti melalui kelompok diskusi, kegiatan ekstrakurikuler dan sebagainya. Dalam Pendidikan nonformal, dapat disosialisasikan melalui pelatihan-pelatihan dengan model pembelajaran yang responsive multikultural dengan mengedepankan penghormatan terhadap perbedaan baik ras, suku, maupun agama antaranggota masyarakat. Dalam lingkup keluarga sebagai institusi sosial terkecil dalam masyarakat, merupakan lembaga pendidikan yang paling efektif dalam proses internalisasi dan transformasi nilai, serta sosialisasi terhadap anggota keluarga. Peran orangtua dalam menanamkan nilainilai yang lebih responsive multikultural dengan mengedepankan penghormatan dan pengakuan terhadap perbedaan yang ada di sekitar lingkungannya (agama, ras, golongan) kepada anak atau anggota keluarga yang lain merupakan cara yang paling efektif dan elegan untuk mendukung terciptanya sistem sosial yang kondusif.

2. Pendidikan multikultural adalah gerakan pembaharuan dan inovasi pendidikan yang sangat relevan dengan ajaran Islam sebagai upaya untuk menanamkan kesadaran pentingnya hidup bersama dalam keberagaman dan perbedaan, dengan spirit hidup rukun dan damai, saling percaya, saling memahami dan menghargai persamaan, perbedaan dan keunikan agama-agama, sehingga terjalin suatu relasi dan interdependensi dalam situasi saling mendengar dan menerima perbedaan pendapat dalam pikiran terbuka, untuk menemukan jalan terbaik mengatasi konflik dan menciptakan perdamaian melalui kasih sayang antar sesama, karena sudah menjadi sunnatullah manusia hidup dalam keberagaman dan yang paling mulia dalam penilaian Allah swt. adalah yang paling bertaqwa.

\section{B. Implikasi}

Untuk terwujudnya pendidikan multikultural yang dinamis, dalam arti setiap warga masyarakat lebih mengedepankan kebersaamaan dibanding perbedaanperbedaan, kerjasama dalam hal yang disepakati toleransi dalam perbedaan, maka pendidikan multikultural perlu diintegrasikan dalam kurikulum bidang studi yang relevan pada semua jenjang pendidikan, mulai dari PAUD sampai Perguruan Tinggi. Karenanya, para penentu kebijakan pendidikan dalam arti yang luas, tokoh agama dan tokoh masyarakat bahkan pada setiap penanggung jawab keluarga perlu menata dan mengelola serta menerapkan pendidikan multikultural dengan sebaik-baiknya. 


\section{DAFTAR PUSTAKA}

Abdulsyani. Sosiologi: Skematika, Teori dan Terapan. Cet. I; Jakarta: Bumi Aksara, 1994.

Ali, Muhammad. Teologi pluralis-multikultural: Menghargai Kemajemukan Menjalin Kebersamaan. Jakarta: Kompas, 2003.

Departemen Agama RI. Alquran dan Terjemahnya. Jakarta: CV. Pustaka Agung Harapan, 2002.

Ghazali, Abd. Moqsith. Argumen Pluralisme Agama: Membangun Toleransi Berbasis Alquran (Cet. II; Jakarta: KataKita, 2009.

Ma'hady, Muhaemin El. Multikulturalisme dan Pendidikan Multikultural, http://researchengines.com/muhaemin6-04.html.

Mahfud, Choiril. Pendidikan Multikulturisme (Cet. II; Yogyakarta: Pustaka Pelajar, 2008.

Narwoko, J. Dwi dan Bagong Suyanto. Sosiologi: Teks Pengantar dan Terapan. Cet. III; Jakarta: Kencana, 2007.

Poerwanto, Hari. Kebudayaan dan Lingkungan: Dalam Perspektif Antropologi. Cet. II; Yogyakarta: Pustaka Pelajar, 2005.

Rahmat, Pupu Saeful. http://akhmadsudrajat.wordpress.com/2008/04/04/wacanapendidikan-multikultural-di-indonesia/4 April 2008 by Akhmad Sudrajat.

Ritzer, George dan Douglas J. Goodman. Modern Sociological Theory dialihbahasakan oleh Alimandan dengan judul: Teori Sosiologi Modern. Cet. V; Jakarta: Kencana, 2008.

Sairin, Sjafri. Perubahan Sosial Masyarakat Indonesia: Perspektif Antropologi. Cet. I; Yogyakarta: Pustaka Pelajar, 2002.

Salim, Agus. Pengantar Sosiologi Mikro. Cet. I; Yogyakarta: Pustaka Pelajar, 2008.

Soekanto, Soerjono. Sosiologi Suatu Pengantar. Jakarta: PT. RajaGrafindo, 2009.

Soeprapto, R. Riyadi. Interaksionisme Simbolik: Perspektif Sosiologi Modern. Cet. I; Malang: Averroes Press, 2002.

Sugiharta, Andipostra dan Andi. http://id.shvoong.com/social-sciences/1918568pendidikan-multikultural.

Sumartana, Th. dkk. Pluralisme, Konflik dan Pendidikan Agama di Indonesia (Yogyakarta: Pustaka Pelajar, 2001.

Susan, Novri. Sosiologi Konflik: Isu-isu Konflik Kontemporer. Cet. I; Jakarta: Kencana, 2009. 
Tafsir, Ahmad. llmu Pendidikan Dalam Perspektif Islam. Cet. II; Bandung: Remaja Rosdakarya, 1994.

Tilaar, H.A.R. Perubahan Sosial dan Pendidikan: Pengantar Pedagogik Transformatif untuk Indonesia, Jakarta, Grasindo, 2002.

Wulansari, C. Dewi. Sosiologi Konsep dan Teori. Cet. I; Bandung: Refika Aditama, 2009. 